\title{
KONTRIBUSI UNHCR DALAM PENANGANAN PENGUNGSI INTERNASIONAL DI INDONESIA
}

\author{
Joko Setiyono \\ Fakultas Hukum Universitas Diponegoro \\ Jl. Prof. Soedarto, SH No. 1 Kampus Tembalang Semarang \\ jokosetiyono61@yahoo.com
}

\begin{abstract}
UNHCR is the United Nations specialized organs formed for the purpose of protecting and guaranteeing human rights and international efforts to humanise refugees, as a result of a war or a prolonged armed conflict, internal strife and other domestic issues. Handling refugee who came from Indochina Peninsula, the ethnic Rohingya refugees, East Timor's refugees, at least is clear evidence of the contribution of UNHCR in the handling of international refugee issues in Indonesia.
\end{abstract}

Keywords: UNHCR, Refugees International, Contributions, Indonesia

\begin{abstract}
Abstrak
UNHCR merupakan organ khusus PBB yang dibentuk untuk tujuan melindungi dan menjamin HAM serta upaya memanusiawikan para pengungsi internasional, sebagai akibat dari suatu peperangan ataupun konflik bersenjata yang berkepanjangan, pertikaian internal dan berbagai persoalan dalam negeri lainnya. Penanganan pengungsian yang berasal dari Semenanjung Indochina, pengungsi etnis Rohingya, pengungsi eks Timor Timur, setidaknya merupakan bukti nyata adanya kontribusi UNHCR dalam penanganan permasalahan pengungsi internasional di Indonesia.
\end{abstract}

Kata Kunci: UNHCR, Pengungsi Internasional, Kontribusi, Indonesia

\section{A. Pendahuluan}

Berbagai persoalan internasional menunjukan kecenderungan yang semakin kompleks dalam bidang kehidupan, sehingga memerlukan strategi penanganan komprehenshif dari masyarakat internasional. Negara sebagai salah satu subyek Hukum Internasional (Thontowi \& Iskandar, 2006) merupakan change of agency yang berperan aktif dalam pengembangan dan pentransformasian eksistensi Hukum Internasional guna mengatasi berbagai persoalan didalamnya. Seiring dengan perkembangan waktu, eksistensi negara sebagai aktor tunggal dalam percaturan internasional mengalami pergeseran, dikarenakan munculnya berbagai subjek Hukum Internasional selain negara, yang dalam konteks ini adalah munculnya berbagai organisasi internasional, satu diantaranya United Nations High
Commissioner for Refugee (UNHCR) (Setianingsih Suwardi, 2004).

Kemunculan organisasi internasional diperlukan dalam kerangka kerja sama menyesuaikan dan mencari kompromi untuk menentukan kesejahteraan serta memecahkan berbagai persoalan bersama serta mengurangi pertikaian yang timbul. Organisasi Internasional beserta alat perlengkapannya mempunyai hak, kewajiban dan kekuasaan, sebagaimana dimiliki alat perlengkapan negara modern yang juga diatur oleh hukum konstitusi internasional (Mauna, 2000). Patut dikemukakan, walaupun organisasi internasional baru muncul abad ke-19, akan tetapi perkembangannya yang sangat cepat setelah berakhirnya Perang Dunia II, antara lain memiliki ciri sebagai persekutuan antara negara-negara yang secara permanen, dengan tujuan yang sesuai dengan hukum, dilengkapi 
dengan organ-organnya.(Parthiana, 1990)

Untuk mencapai maksud dan tujuan PBB sebagai organisasi internasional, diciptakanlah alat kelengkapan/organ utama, seperti : Majelis Umum, Dewan Keamanan, Dewan Ekonomi dan Sosial, Dewan Perwalian, Mahkamah Internasional dan Sekretariat PBB. Selanjutnya untuk membantu kelancaran tugas dan tujuannya, alat kelengkapan/organ utama dibantu oleh badan-badan khusus PBB antara lain : UNESCO); WHO; IMF; ILO; FAO dan lainlain. Selain itu, ECOSOC mempunyai badanbadan yang turut membantu badan-badan tambahan (subsidiary organs) yang dibentuk oleh Majelis Umum seperti UNCTAD, UNICEF, dan United Nations High Commissioner for Refugee (UNHCR).

Diantara banyaknya alat kelengkapan maupun specialized agencies yang dimiliki PBB, hanya UNHCR yang merupakan subsidiary organs serta organisasi internasional khusus yang dibentuk untuk melindungi dan menjamin hak asasi pengungsi dari ketidakadilan. Fakta empiris menunjukkan dengan adanya dua perang dunia dan sekitar ratusan pertikaian bersenjata, telah membuat jutaan orang mengungsi dan melakukan eksodus ke berbagai belahan dunia yang dianggap aman dari ancaman persekusi, konflik bersenjata atau kekerasan politik lainnya. Persoalan terkait dengan pengungsi sudah menjadi perhatian masyarakat internasional sejak berakhirnya Perang Dunia I, utamanya pasca runtuhnya Kekaisaran Rusia (1917) dan Kekaisaran Ottoman Turki (1918), yang mengakibatkan terjadinya pengungsian massal orang-orang dari wilayah yang berada di bawah rezim baru (Suprapto, 2001). Permasalahan pengungsi yang telah menjadi persoalan pelik dan kompleks hingga saat ini, menjadi salah satu agenda UNHCR untuk memanusiawikan para pengungsi, orangorang yang dipindahkan, orang-orang yang dipulangkan dan orang-orang tanpa kewarganegaraan, sebagai salah satu korban akibat perang, pertikaian internal maupun masalah dalam negeri lainnya.

Penghormatan terhadap Hak Asasi Manusia (HAM) merupakan syarat penting untuk mencegah dan menyelesaikan masalah pengungsi. Kompleksitas permasalahan yang tanpa diimbangi dengan adanya peraturan standar minimum mengenai pengungsi, menyebabkan Majelis Umum PBB memutuskan untuk menyelenggarakan konferensi PBB tentang Status Pengungsi dan Orang-Orang Tanpa Kewarganegaraan (United Nation Conference of Plenipotentiaries on The Status of refugees and Stareless Persons).

Konvensi 1951 merupakan suatu instrumen internasional bagi pengungsi, yang rancangannya dibuat sebagai hasil rekomendasi Komisi HAM PBB dan berisi aturan standar perlakuan terhadap pengungsi. Konvensi telah menetapkan status hukum pengungsi dan mencantumkan ketentuan-ketentuan tentang hak dan kewajiban mereka untuk mendapatkan apa yang menjadi hak dan kewajiban pengungsi pada umumnya. Berlakunya Konvensi 1951 terhadap para pengungsi ini juga diikuti dengan berlakunya Protokol 1967, yang mengatur secara rinci mengenai status kedudukan dari pengungsi. Berlakumya Konvensi 1951 dan Protokol 1967 telah memberikan langkah dan prinsip baru mengenai definisi dari pengungsi dan perlindungan signifikan yang berbasis dari status atau kedudukan resmi para pengungsi. Selain itu, kedua instrumen internasional tersebut juga memberikan arah bagi $U N H C R$ untuk menjalankan eksistensinya didalam melindungi hak dan kewajiban pengungsi yang tersebar di belahan dunia.

Banyaknya pelanggaran HAM maupun hak minimum pengungsi yang terus berkembang, membuat kontribusi UNHCR sebagai organisasi khusus PBB dalam membantu menyelesaikan berbagai persoalan terkait pengungsiaan menjadi sangat penting dan strategis dewasa ini. Terkait dengan isu dasar itulah, maka dipandang perlu untuk dilakukannnya suatu penelitian, yang hasil akhirnya dituangkan dalam makalah ini. Permasalahan utama dalam penulisan ini adalah: pertama, apakah yang melatarbelakangi munculnya $U N H C R$ sebagai organisasi internasional yang menangani permasalahan pengungsian? kedua, bagaimana kontribusi UNHCR dalam mengatasi permasalahan pengungsi 
internasional di Indonesia

\section{B. Pembahasan}

1. Latar Belakang UNHCR sebagai Organisasi Internasional Di Bawah PBB Yang Diberi Kewenangan mengatasi Permasalahan Pengungsi Internasional

Instrumen internasional yang dapat dipergunakan sebagai dasar hukum terkait dengan pengungsi internasional, antara lain : pertama, traktat universal yang terdiri dari Konvensi 1951 dan Protokol 1967; kedua, traktat regional diantaranya Konvensi Organisasi Persatuan Afrika tentang Berbagai Aspek Masalah Pengungsi Di Afrika; ketiga, Hukum Kebiasaan Internasional yang terkait dengan prinsip non-refoulement, dimana semua negara terikat secara hukum untuk melarang melakukan pengembalian atau pemulangan pengungsi dengan cara apapun ke negara atau wilayah dimana kelangsungan hidup atau kebebasan mereka terancam dikarenakan ras, agama, kebangsaan, keanggotaannya dalam kelompok sosial tertentu atau pendapat politiknya.

Instrumen hukum utama tentang pengungsi dalam Konvensi 1951 dan Protokol 1967, yang terpenting adalah : pertama, perlindungan harus diberikan kepada semua pengungsi tanpa melakukan pembedaan; kedua, standar minimum perlakuan yang harus diperhatikan terhadap pengungsi; ketiga, pengusiran seorang pengungsi dari negara suaka merupakan hal yang sangat serius; keempat, pemberian suaka merupakan beban yang tidak tertanggungkan bagi beberapa negara tertentu; kelima, perlindungan pengungsi merupakan tindakan kemanusiaan, oleh karenanya pemberian suaka tidak seharusnya menimbulkan ketegangan diantara negaranegara; keenam, negara harus bekerjasama dengan UNHCR dalam melaksanakan fungsinya dan untuk memfasilitasi tugastugasnya dalam mengawasi diterapkannya konvensi.

Permasalahan pengungsi yang didalamnya juga menyangkut HAM, memunculkan kepedulian dari masyarakat internasional untuk memberikan perlindungan melalui pembentukan sebuah organisasi internasional yang bersifat khusus yang berada dibawah naungan PBB. Berdasarkan SU PBB 1946 telah menyetujui suatu Resolusi No. 319A (IV) 1949 yang meletakkan dasar bagi kegiatan PBB yang berkaitan dengan pemberian bantuan kepada para pengungsi. Selain itu, Resolusi juga menyebutkan bahwa para pengungsi atau orang yang terusir yang telah mengemukakan rasa keberatan yang sah untuk dikembalikan ke negara asalnva tidak harus tunduk pada upaya pemulangan tersebut. Hal inilah yang menyebabkan PBB membentuk International Refugees Organisation (IRO), dengan tujuan utama adalah repatriasi, tetapi ketegangan politik yang akhirnya mencetuskan Perang Dingin telah mengubah arah kebijakan menjadi memukimkan kembali (resettlement). Selanjutnya, tahun 1951 IRO berganti nama menjadi UNHCR yang bermarkas di Jenewa, Swiss. Pembentukan UNHCR dimaksudkan untuk melindungi dan memberikan bantuan kepada para pengungsi internasional, serta mendampingi para pengungsi dalam proses pemindahan tempat menetap mereka ke tempat yang baru.

Dalam perkembangannya UNHCR tidak hanya menolong orang yang terlantar dan kehilangan tempat tinggalnya, tetapi juga menolong orang yang masih jadi pengungsi atau hidup dalam pengungsian, memberikan perlindungan internasional dan mengupayakan solusi permanen terhadap masalah pengungsi, melindungi atau membantu kelompok-kelompok khusus orang-orang yang terusir secara internal dan perbatasan internasional, namum berada dalam situasi seperti yang dialami pengungsi di negara mereka sendiri.

Upaya UNHCR untuk menemukan solusi permanen atas masalah yang dihadapi, berawal dari kebutuhan akan berbagai hak (asasi) utama setiap pengungsi sebagai individu makluk Tuhan (Moniz, 2013) dilakukan dengan: pertama, mendorong pemerintahan negara-negara di dunia untuk memberlakukan konvensi dan upaya regional dan internasional yang berkaitan dengan pengungsi dan orang-orang yang terusir serta menjamin bahwa standar yang ditetapkan benar-benar dilaksanakan secara efektif; kedua, mengupayakan pemberian suaka 
kepada pengungsi yakni menjamin bahwa kepada pengungsi diberikan rasa aman dan mereka dilindungi dari pemulangan paksa ke negara yang mereka khawatirkan akan melaksanakan persekusi atau penganiayaan terhadap mereka; ketiga, menjamin bahwa para pengungsi diperlakukan sesuai dengan standar yang diakui secara internasional dan memperoleh status hukum yang memadai, termasuk sejauh memungkinkan hak-hak ekonomi dan sosial yang sama dengan diberikan kepada warganegara di negara yang memberi mereka suaka; keempat, menjamin penyelesaian permanen bagi pengungsi baik melalui repatriasi sukarela ke negara asal mereka, atau, jika hal itu tidak memungkinkan, menjadi warga negara di negara yang menjadi tempat tinggal atau domisili mereka; kelima, membantu reintegarsi pengungsi kembali ke negara asalnya melalui konsultasi dengan pemerintah yang bersangkutan serta memantau amnesti atau jaminan yang diberikan sebagai syarat kepulangan mereka; keenam, mengupayakan keselamatan fisik pengungsi, pencari suaka, dan returnee, khususnya keselamatan mereka dari militer dan tindak kekerasan lainya; ketujuh, memperjuangkan reunifikasi keluargakeluarga pengungsi.

Orang-orang yang menjadi urusan UNHCR adalah semua orang yang kebutuhan perlindungan dan bantuannya menjadi perhatiannya, yang mencakup: para pengungsi menurut Konvensi Pengungsi Tahun 1951; orang-orang yang melarikan diri dari konflik atau gangguan serius atas ketertiban umum, yaitu pengungsi menurut definisi Konvensi Organisasi Persatuan Afrika dan Deklarasi Kartagena; orang-orang yang telah kembali ke negara asal para pengungsi; dan orang-orang yang tersingkirkan di dalam negeri.

\section{Kontribusi UNHCR dalam Mengatasi Permasalahan Pengungsi Internasional Di Indonesia}

Dewasa ini, perlindungan terhadap pengungsi masih menjadi alasan bagi keberadaan $U N H C R$. Setidaknya data UNHCR telah menyebutkan bahwa jumlah pengungsi, antara lain berasal dari Afganistan (2,3 juta), Rwanda (1,7 juta), Bosnia dan
Herzegovina (1,3 juta), Liberia (750.000), Irak (630.000), Somalia (466.000), Sudan (424.000), Eritrea (362.000), Angola (324.000), dan Sierra Leone (320.000).

Penanganan permasalahan pengungsi internasional didorong oleh rasa kemanusiaan untuk memberi perlindungan dan memberikan rasa aman dan nyaman terhadap para pengungsi yang ke luar dari negaranya karena tidak mendapat perlindungan sebagaimana mestinya. Patut dikemukakan bahwa kedudukan sebagai pengungsi tidak berlaku abadi, artinya bisa berhenti, persoalan yang timbul adalah jangan sampai pengungsi itu bisa dirugikan statusnya sebagai pengungsi secara sewenang-wenang. Oleh karenanya pula, maka setiap pengungsi berkewajiban untuk mematuhi semua hukum dan peraturan atau ketentuan-ketentuan untuk menciptakan ketertiban umum di negara dimana dia berada atau ditempatkan. Konvensi 1951 dan Protokol 1967 telah menentukan siapa yang dapat diakui sebagai pengungsi. Penetapan status sebagai pengungsi sangat penting, untuk dapat menikmati hak-hak yang ditentukan Konvensi 1951 dan Protokol 1967 atau tunduk pada kewenangan $U N H C R$.

Adapun tahapan yang harus dilalui oleh pengungsi di suatu negara, yaitu : pertama, registrasi pemohon pengungsi; kedua, wawancara tahap awal; ketiga, penentuan status pengungsi. Registrasi pemohon pengungsi berisi dokumen resmi yang memuat identitas lengkap pengungsi berikut alasan pergi dari negara asal. Selanjutnya, UNHCR akan mengeluarkan attestation letter memuat prinsip non refoulement, yaitu pelarangan suatu negara mengembalikan atau mengusir, maupun mengirim pengungsi dan pencari suaka ke wilayah dimana akan terancam kehidupan dan keselamatan pengungsi dan pencari suaka. Wawancara tahap awal adalah wawancara yang dilakukan oleh UNHCR untuk menggali lebih dalam mengenai kasus dari seorang pemohon pengungsi sebelum diberikan rekomendasi untuk diterima atau ditolak kasusnya.

Penentuan status pengungsi adalah suatu tahap dimana setelah selesai wawancara, dilanjutkan pada penyelesaian kasus hingga memberikan laporan dan 
rekomendasi ditolak atau diterima oleh $U N H C R$. Bagi yang diterima dan dinyatakan layak sebagai pengungsi, maka diberikan status sebagai pengungsi internasional oleh UNHCR melalui penerbitan refugee certificate. Penampungan sementara pengungsi yang telah memperoleh status sebagai pengungsi internasional dari $U N H C R$ dan dipenuhi kebutuhan dasarnya dengan dana sumbangan atau donor negara-negara anggota. Pengungsi yang berada di negara penampungan yang belum meratifikasi Konvensi 1951 dan Protokol 1967, maka akan kehilangan hak untuk memperoleh pekerjaan. Oleh karenanya, UNHCR dapat melakukan penempatan pengungsi di negara peserta.

Penanganan pengungsian dapat dilakukan UNHCR melalui: repatriasi sukarela, permukiman lokal, dan pemukiman kembali di negara ketiga. Penangan melalui repratiasi sukarela sangat bergantung pada faktor kondisi di negara asal yang kondusif, sebagaimana UNHCR mengupayakan pemulangan 47 ribu pengungsi Kamboja secara sukarela dari Thailand. Demikian pula pada repatriasi sekitar 1,7 juta pengungsi Mozambique yang kembali antara tahun 1993. Selain itu, UNHCR juga mengupayakan bantuan-bantuan bagi proyek pemukiman lokal, baik wilayah pedesaan maupun kota kepada pengungsi. Bagi pengungsi yang tidak dapat kembali ke negara asal atau tidak merasa aman di negara yang menampungnya, satu-satunya solusi adalah dimukimkan di negara ketiga. Pada tahun 1996 sekitar 35.000 pengungsi dari sekitar 40 negara penampung dimukimkan kembali oleh $U N H C R$ ke berbagai negara di dunia.

$U N H C R$ mengidentifikasi berbagai faktor penyebab terjadinya pengungsian internasional. Faktor politik biasanya terkait dengan penyalahgunaan kekuasaan penguasa dan aparat keamanan penyebab terjadinya berbagai pelanggaran HAM, yang pada akhirnya menimbulkan pengungsian massal ke negara lainnya yang dapat memberikan jamainan keamanan, kesejahteraan, dan penghormatan terhadap harkat dan martabat kemanusiaan. Faktor ekonomi pendorong terjadinya pengungsian internasional, utamanya yang terkait dengan miskinnya suatu negara, krisis ekonomi berkepanjangan, kelaparan, wabah penyakit meluas, kriminalitas meningkat tajam, dan berbagai dampak negatif lainnya, membuat rakyat lebih memilih untuk meninggalkan negara asalnya dan mencari penghidupan tempat di negara lain sebagai tempat mengungsi. Faktor agama juga merupakan salah satu faktor yang mengakibatkan terjadinya pengungsian internasional, sebagaimana terjadi pada pengungsi Palestina, Afghanistan, Etnis Rohingya, dan pengungsi eks Timor Timur. Selain itu, perang juga merupakan faktor terbesar penyebab pengungsian internasional. Mereka yang meninggalkan negaranya biasanya untuk menghindari dampak perang yang berkepanjanjangan ke negara lain yang aman, seperti halnya peperangan yang terjadi di kawasan Timur Tengah, Afganistan, dan kawasan dunia lainnya.

Indonesia mulai menghadapi persoalan pengungsi yang serius pada tahun 1975, dimana ribuan orang meninggalkan wilayah semenanjung Indocina untuk mencari perlindungan di negara lain, sebagai akibat dari pergantian rezim di wilayah tersebut. Kebanyakan dari mereka, terutama dari Vietnam, menggunakan jalan laut sampai di wilayah Indonesia. Terkait hal tersebut, setelah berkoordinasi dengan UNHCR, pemerintah Indonesia menjadikan Pulau Galang sebagai tempat penampungan para pengungsi. Peran UNHCR atas pengungsi tersebut, dilakukan untuk mencari solusi efektif melalui fungsi inisiator, fasilitator, dan determinan.

Dari perspektif sejarah, perpecahan antara etnis Rohingya dan pemerintah Myanmar sebenarnya sudah terjadi sejak puluhan tahun silam hingga saat ini. Penyebab utama perpecahan yang berlanjut pada suatu konflik bersenjata berkepanjangan, selain terkait dengan faktor Sara, juga ada faktor bahasa, dan faktor ekonomi serta pengelolaan lahan pertanian. Dampak perpecahan tersebut menyebabkan terjadinya arus pengungsian besar-besaran etnis Rohingya ke berbagai wilayah negara yang dipandang aman dan bersedia 
menampung para pengungsi, termasuk dalam wilayah Indonesia.

Berbagai upaya telah dilakukan dalam kerangka untuk menjadikan warga etnis Rohingya menjadi warga asli Myanmar, walaupun belum membuahkan hasil yang diharapkan, dikarenakan dari pihak pemerintah Myanmar sendiri tidak mau menerima etnis Rohingya sebagai warga negaranya dan menganggap sebagai imigran gelap dari negara Bangladesh. Dalam menangani pengungsi Rohingya di Indonesia, UNHCR sebagai organisasi internasional telah menjalankan perannya untuk memonitor dan mencari penyelesaian terhadap permasalahan, serta menjalankan perannya sebagai inisiator, fasilitator, dan determinan dengan baik. Menjamin bahwa setiap orang berhak untuk mencari suaka dan mendapat tempat yang aman di negara lain, dengan pilihan kembali secara sukarela ke negaranya, lokal integrasi atau penempatan ke negara ketiga.

Sebagai komunitas yang sudah lama menetap di sebuah wilayah yang kebetulan sekarang telah menjadi bagian wilayah di negara Myanmar, tentu saja sudah selayaknya mereka mendapatkan hak-hak dasar mereka, terutama status kewarganegaraan. Meskipun Myanmar tak mungkin memberikan kewarganegaraan kepada Rohingya, namun demikian tetap menawarkan solusi berupa pengiriman ribuan etnis Rohingya ke negara lain atau tinggal di Arakan di bawah pengawasan PBB, namun sayang hingga kini hal tersebut belum dapat direalisasikan, sehingga oleh Indonesia peran $U N H C R$ sebagai organisasi internasional di bawah PBB masih tetap diharapkan.

Terkait dengan adanya pengungsi etnis Rohingya di Indonesia, UNHCR juga telah berperan sebagai inisiator dengan baik. Sebagai catatan di tahun 2009, ada sekitar 391 pengungsi Rohingya mengungsi ke Indonesia, yang mana $U N H C R$ terus memantau dan memastikan sifat repatrias $i$ secara sukarela dan memberikan bantuan. Para pengungsi Rohingya ditampung di tempat pengungsian dalam pengawasan
UNHCR, yaitu di kamp pengungsian TNI AL, kantor Camat di wilayah Aceh, dan di beberapa rumah warga lainnya (Januari, 2013).

Selanjutnya terkait dengan pengungsi warga eks Timor-Timur pasca jajak pendapat tahun 1999, UNHCR telah menjamin bantuan pemulangan pengungsi dari kamp-kamp pengungsian, setelah warga Timor Timur mengutarakan keinginan mereka untuk meninggalkan kamp dan pulang ke negara asalnya dengan rasa aman dan terlindungi.

\section{Simpulan}

Berdasarkan pada hasil pembahasan tersebut di atas, maka dapat disimpulkan, sebagai berikut:

1. Terkait pengungsi internasional, telah memunculkan kepedulian masyarakat internasional untuk memberikan perlindungan kepada para pengungsi melalui pembentukan sebuah organisasi internasional dibawah $\mathrm{PBB}$, dengan nama $U N H C R$. Berdasarkan Konvensi 1951 dan Protokol 1967, maka semua pengungsi itu wajib dilindungi oleh setiap negara, baik negara tujuan maupun negara tempat transit para pengungsi international.

2. UNHCR merupakan sebuah badan pengungsi dunia yang diberi mandat oleh PBB untuk melindungi pengungsi dan membantu pengungsi mencari solusi bagi keadaan buruk para pengungsi internasional. Kontribusi UNHCR atas pengungsi internasional di Indonesia, tampak dalam penanganan pengungsian yang berasal dari Semenanjung Indochina, pengungsi etnis Rohingya, pengungsi eks Timor Timur,

\section{DAFTAR PUSTAKA}

Januari, N. (2013). Peran United Nation High of Commissioner for Refugees (UNHCR) Dalam Menangani Pengungsi Rohingya di Aceh Tahun 2009-2010. E-Journal.hi.fisipUnmul.org.

Mauna, B. (2000).Hukum internasional 
Pengertian Peranan Dan Fungsi Dalam Era Dinamika Global. Bandung: Alumni.

Moniz, L. (2013). Peranan United Nations High Commission For Refugees (UNHCR) Dalam Penanganan Pengungsi Timor Leste Di Indonesia Pasca Referendum Tahun 1999. Bandung.

Parthiana, I. W. (1990).Pengantar Hukum Internasional. Bandung: Mandar Maju.

Setianingsih Suwardi, S. (2004).Pengantar Hukum Organisasi Internasional (1st ed.). Jakarta: UI Press.

Suprapto, E. (2001). Kentuan-ketentuan Utama Konvensi 1951/Protokol 1967 Mengenai Status Pengungsi. In Perlunya Indonesia Mengaksesi Konvensi Tentang Pengungsi (p. 1). Jakarta: Pusat Studi Hukum Humaniter FH Universitas Trisakti.

Thontowi, J., \& Iskandar, P. (2006). Hukum Internasional Kontemporer. Bandung: PT. Refika Aditama. 